\title{
Araucaria heterophylla and Pinus caribaea: potential Christmas trees for Puerto Rico'
}

\author{
Thomas H. Schubert and José A. Zambrana ${ }^{2}$
}

\begin{abstract}
Araucaria heterophylla was the most promising of six evergreen species tested for suitability as Christmas trees. Pinus caribaea var. hondurensis may also be usable. Callitris intratropica, Casuarina equisetifolia, and Cryptomería japonica grew well but had poor appearances, and Pinus echinata failed.
\end{abstract}

\section{INTRODUCTION}

Christmas trees, a traditional part of the holiday celebration for many families in Puerto Rico, are not grown commercially on the island. In recent Decembers local newspapers featured articles about trees imported from Canada or the United States mainland. These articles show that the price of an average 6 foot $(1.8 \mathrm{~m})$ tree-increased from less than $\$ 20$ in 1976 to $\$ 35$ or more in 1979 , that the trees are often misshapen or have sparse foliage, and that either too few or too many trees have arrived. ${ }^{3}$

If suitable trees could be grown in Puerto Rico, the price to consumers could be lower, and the money spent for imports would remain on the island and benefit local landowners and workers. Also, trees would be fresher because they could be cut much closer to the time of use. And the number of trees cut could be more accurately matched to the demand: One island economy, Hawaii, has already coped by growing Araucaria heterophylla as a Christmas tree for more than 15 years. ${ }^{4}{ }^{4}$ This species and others were planted by the Institute of Tropical Forestry, in cooperation with the Agricultural Experiment Station of the University of Puerto Rico, to test the possibility of growing Christmas trees in Puerto Rico. This note reports the results of the trial

\section{MATERIALS AND METHODS}

The following six evergreen species were used: Araucaria heterophylla (Salisb.) Franco; Callitris intratropica R. T. Bak. et H. G. Sm.; Casuar-

${ }^{1}$ Manuscript submitted to Editorial Board December 2, 1980.

${ }^{2}$ Southern Forest Experiment Station, USDA, Institute of Tropical Forestry, Rio Piedras, P.R.; and Forest Service, Department of Natural Resources, Commonwealth of Puerto Rico.

${ }^{3}$ San Juan Star. Articles and photos dated Dec. 12, 1976; Dec. 12, 1977; Dec. 3, 1978; and Nov. 29, 1979.

${ }^{4}$ LeBarron, Russell K., 1965. Growing Norfolk Island Christmas trees in Hawaii, Coop. Ext. Ser., Univ. Hawaii, Misc. Publ. 23.

${ }^{5}$ Fullaway, David T., Tom K. Tagawa, Eduardo Trujillo, C. J. Davis, A. A. La Plante, and Ernest Pung, 1972. Norfolk Island Pine culture, Coop. Ext. Serv., Univ. Hawaii, Circ. 453. 
ina equisetifolia L.; Cryptomeria japonica (L.f.) D. Don; Pinus caribaea var. hondurensis Barrett et Golfari; and Pinus echinata Mill.

The test trees were planted between October 1970 and July 1971 at the Corozal Agricultural Substation in north-central Puerto Rico, on land typical of what might be available for growing Christmas trees. The site is in the Subtropical Moist Forest ecological life zone ${ }^{6}$ and has an annual rainfall of about $2000 \mathrm{~mm}$. Elevation is about $150 \mathrm{~m}$ above sea level, and aspect is south to southwest. The soil is Lares clay, a deep, moderately well-drained, very strongly acid soil, classified as a clayey, mixed, isohyperthermic Aquic Tropohumults.

Eighty seedlings of each species were planted at a spacing of 1.5 by 1.5 $\mathrm{m}$ in four plots of 20 trees each. The seedlings averaged 17 to $22 \mathrm{~cm}$ in height after planting except for the Casuarina, which had an average height of $40 \mathrm{~cm}$. Some trees in two plots of each species were later experimentally sheared, although this was not done often enough to allow definite recommendations to be made for the various species. But to avoid any bias from the shearing, we determined survival and height growth only in the unsheared plots.

\section{RESULTS AND DISCUSGION}

After $2 \frac{1 / 2}{2}$ to 3 years of growth, only Pinus echinata had not survived and grown reasonably well. Araucaria heterophylla was the most promising species. It had $72.5 \%$ survival, and grew an average of $73 \mathrm{~cm}$ per year in height. It has a naturally pyramidal and symmetrical form (fig. 1), and shearing induces division of the branch ends if a fuller appearance is desired. The foliage retains its healthy green color for more than a month after the tree is cut. A 2 to $3 \mathrm{~m}$ tree can be produced within 3 to 4 years after outplanting. If two whorls of live branches are left on the stump when the tree is cut, sprouts will produce a new tree in even less time. ${ }^{5}$ This sprouting can be repeated several times as long as the stump remains healthy. A possible disadvantage is that Araucaria lacks the resinous odor characteristic of firs, pines, and spruces. However, the increasing acceptance of artificial trees, and of trees that have been sprayed with simulated snow or other coatings, indicates that many consumers may be willing to sacrifice aroma for stylized tree form.

Pinus caribaea, with $92.5 \%$ survival and $97 \mathrm{~cm}$ average annual height growth, has. a healthy green color, a reasonably tapered shape (fig. 2), and a resinous odor. But it has widely spaced branches and long needles, which may be less attractive to consumers than the traditional compact

\footnotetext{
${ }^{6}$ Ewel, J. J., and J. L. Whitmore, 1973. The ecological life zones of Puerto Rico and the U.S. Virgin Islands, USDA For. Serv. Res. Pap. ITF-18, 72 p. plus map.

${ }^{7}$ Lugo-López, M. A. and Luis H. Rivera, 1977. Updated taxonomic classification of the soils of Puerto Rico, Agric. Exp. Stn. Univ. P.R. Bull, 258.
} 
and short-needled firs and spruces. Shearing could reduce the spacing between branches, but would need to be done several times a year to be effective. Also, this species tends to dry out rather rapidly after it is cut, even if the base is kept in water, and becomes a fire hazard after two to three weeks. However, it is more widely adapted in Puerto ${ }_{A}$ than is Araucaria, and the tops of trees removed in plantations for posts or

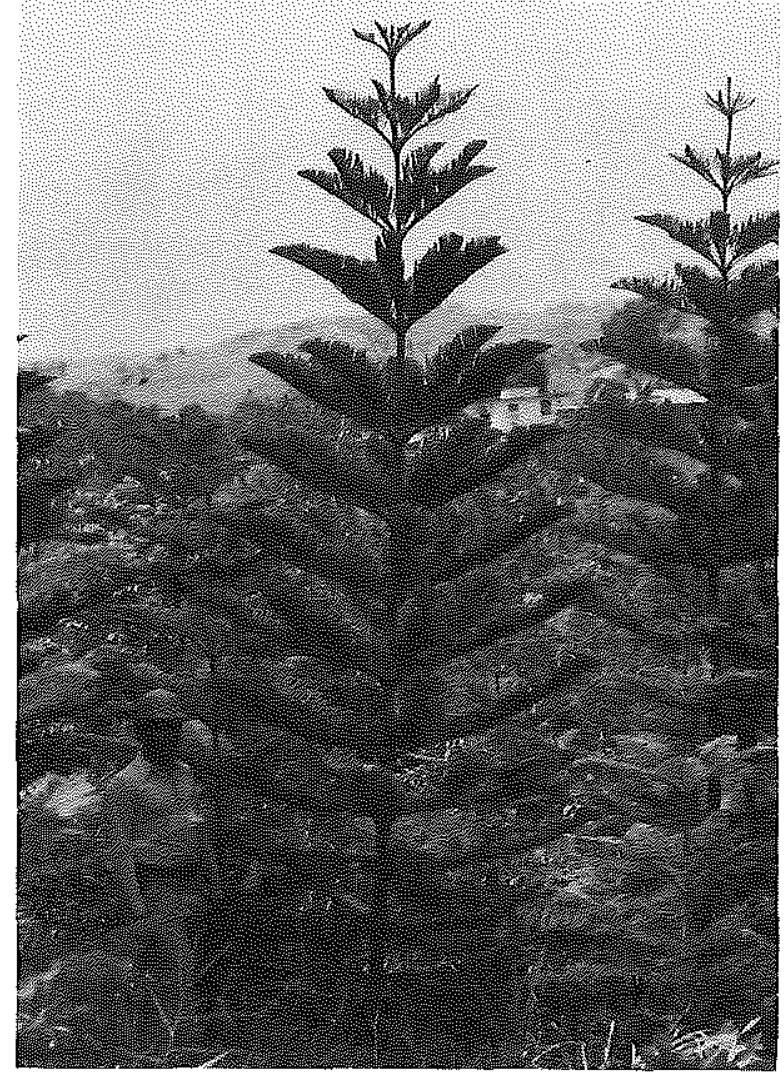

FIG. 1.-Araucaria heterophylla.

other purposes could be sold as Christmas trees if cutting is done just before the holiday season.

The other three species that survived and grew well were unacceptable as Christmas trees because of their appearance. Casuarina, with $100 \%$ survival and more than $300 \mathrm{~cm}$ annual height growth, is sparse and feathery because of its fast growth (fig. 3), and its foliage tends to be gray-green in color. The experimental shearing showed that growth can be controlled to produce a more compact tree, but the shearing would 
need to be repeated at least every two to three months because of the rapid growth rate. Callitris, with $77.5 \%$ survival and $86 \mathrm{~cm}$ annual height growth, has many ascending branches that make it look bushy and multistemmed, and the foliage is at the ends of the branches so that the base of the tree appears bare (fig. 2). Cryptomeria, with $77.5 \%$ survival and 55 $\mathrm{cm}$ annual height growth, lacks the tapered shape of the classical Christmas tree because it is narrow for its height (fig. 2), and the foliage is yellow-green.

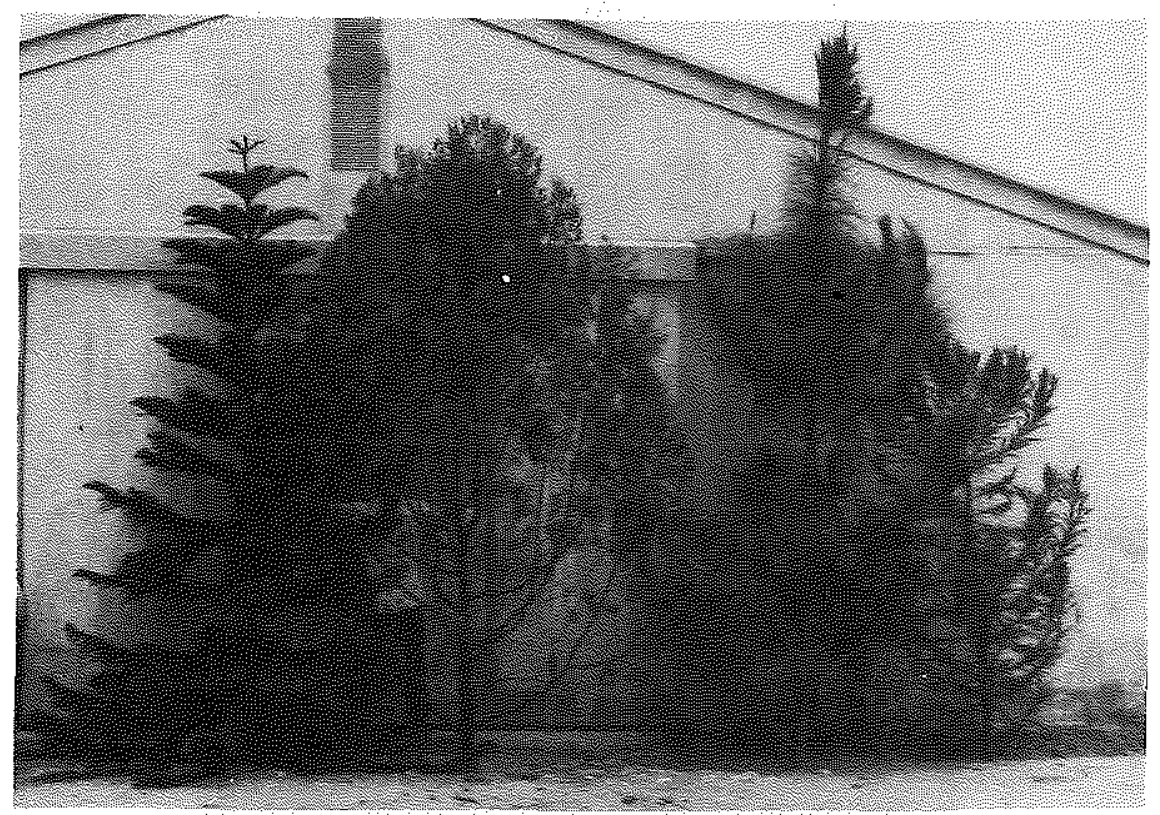

FIG. 2.-From left to right. Araucaria heterophylla, Callitris intratropica. Pinus caribaea, and Cryptomeria japonica.

Pinus echinata had only $32.5 \%$ survival with an average annual height growth of only $36 \mathrm{~cm}$.

Both Araucaria and Pinus caribaea can produce usable Christmas trees in three to four years, at a density of at least 2767 trees per hectare (1097 per cuerda), allowing space for access roads and mechanization. Further trials are needed to determine the adaptability of Araucaria to other sites in Puerto Rico, and to adapt the cultural techniques developed in Hawaii ${ }^{4,5}$ to local conditions.

Also, Araucaria seeds are large and perishable, and there is at present no local source of supply. Both species will require periodic weeding until the young trees have outgrown competing vegetation. Thus, probable 


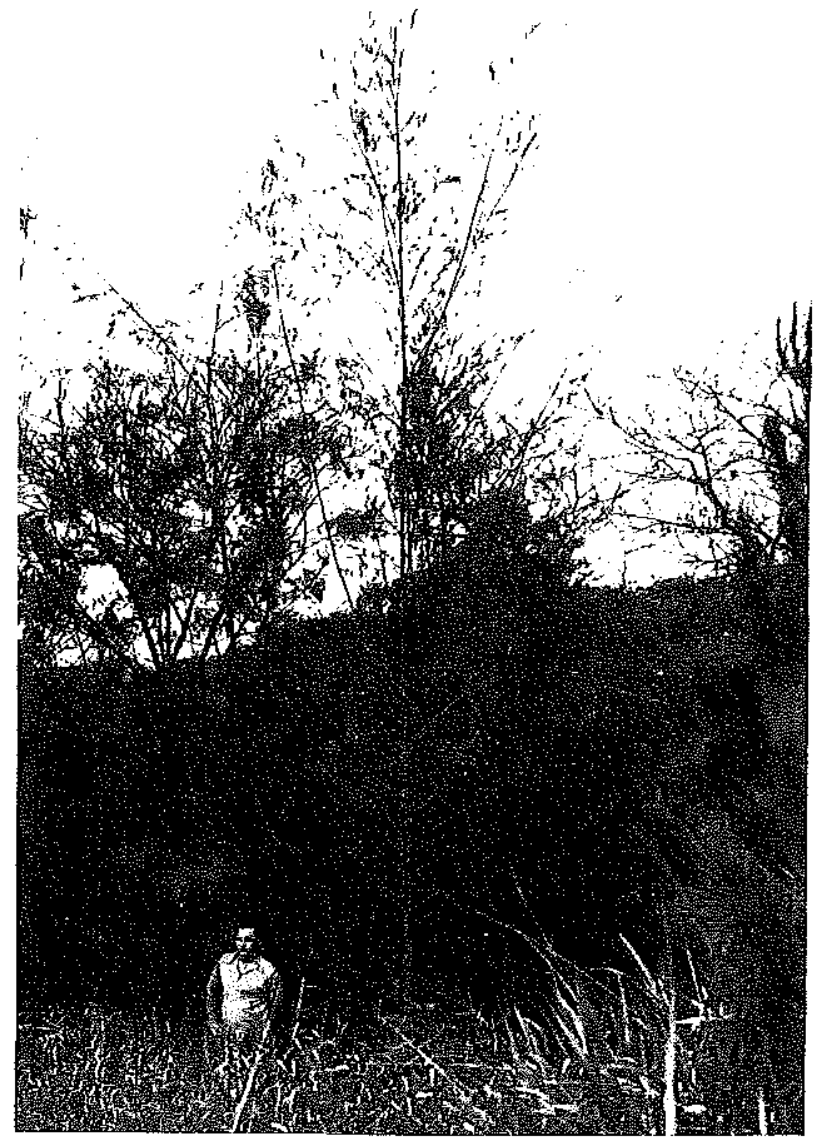

FIG. 3.-Casuarina equisetifolia.

costs and returns of plantations as well as consumer acceptance of the trees produced still need to be determined.

\section{RESUMEN}

Araucaria heterophylla fue la especie más prometedora de las seis especies siempre verdes examinadas para conveniencia como árbol de Navidad. Pinus caribaea var. hondurensis podría ser utilizable también. Calitris intratropica, Casuarina equisetifolia y Cryptomería japonica crecie bien pero poseen una apariencia pobre. Pinus echinata murió. 